\title{
A tissue kallikrein in the synovial fluid of patients with rheumatoid arthritis
}

\author{
B M SELWYN ${ }^{1}$ C D FIGUEROA ${ }^{1}$ E FINK, ${ }^{3}$ A SWAN, ${ }^{2}$ P A DIEPPE, ${ }^{2}$ AND \\ K D BHOOLA ${ }^{1}$
}

From the Departments of ${ }^{1}$ Pharmacology and ${ }^{2}$ Medicine, University of Bristol, Bristol, UK; and the ${ }^{3}$ Institute of Clinical Chemistry and Biochemistry, University of Munich, Munich, FRG

SUMmary Tissue kallikrein is an enzyme that forms the vasoactive peptide kallidin from an endogenous substrate L-kininogen. Tissue kallikrein has been identified in joint fluids and in inflammatory infiltrates within synovial membranes. It is suggested that tissue kallikrein and kinins have an important role in synovitis and joint damage. Immunoreactive tissue kallikrein and amidase activity were both measured in the synovial fluid of 24 patients with rheumatoid arthritis (RA) and 12 with osteoarthritis (OA). Active enzyme concentrations were higher in RA than in $\mathrm{OA}$ and correlated well with the lysosomal enzymes $\beta$-glucuronidase and lactate dehydrogenase. Both total immunoreactive tissue kallikrein and the proenzyme values were similar in RA and OA. Tissue kallikrein was localised by immunocytochemistry to the polymorphonuclear leucocytes present in the synovial fluid and membranes of patients with RA.

Key words: amidases, polymorphonuclear leucocytes, inflammation.

Tissue kallikreins are a family of closely related serine proteases of physiological importance. Their tissue specific functions are largely unknown, but they are known to produce the inflammatory mediator kallidin (lysyl-bradykinin). ${ }^{1}$ Kallidin belongs to the group of vasoactive peptides known as kinins. Many of the effects of kinins, including vasodilatation, increased vascular permeability, leucotaxis, and pain, occur in inflammatory joint disease. ${ }^{2}$ When bradykinin was injected into the knees of dogs it produced acute heat, pain, and effusion. ${ }^{3}$ Furthermore, both bradykinin ${ }^{4}$ and kallidin $^{5}$ have recently been put forward as possible mediators of bone resorption. In 1957 Armstrong et al first described a pain producing substance similar to bradykinin in the synovial fluid of patients with rheumatoid arthritis (RA). ${ }^{6}$ Although bradykinin had been reported in fluid from inflamed ${ }^{3}$ and gouty ${ }^{7}$ joints, it was only later shown to be present in greater amounts than in osteoarthritic (OA) joints. $^{8}$

Accepted for publication 28 June 1988.

Correspondence to Dr K D Bhoola, Department of Pharmacology, University of Bristol, The Medical School, University Walk, Bristol BS8 1TD.
Plasma kallikrein, the serine protease that forms bradykinin, is a component of the intrinsic blood $\overline{\overline{0}}$ coagulation cascade and was first implicated in gout by Kellermeyer and Breckenridge. ${ }^{9}$ Subsequently, plasma kallikrein was detected in RA synovial fluid by Jasani $e t$ al,$^{10}$ and it has recently been shown that significantly higher activity is present in RA than in OA synovial fluid. ${ }^{11}$ Unlike plasma kallikrein, tissue kallikrein has hitherto not been positively identified in joint fluid. The two enzymes differ in structure, physicochemical and immunological properties, and in their susceptibility to inhibitors. ${ }^{12}{ }^{13}$ Tissue kallikrein in cells and in biological fluids exists in one of $\frac{7}{2}$ multiple forms: as an active enzyme, as a proenzyme activated by limited proteolysis, and as an inactive $N$ complex bound to selective protease inhibitors. Our $N$ interest in the possible role of tissue kallikrein in $N$ RA was prompted by the observation that increased $\omega$ amounts of anionic tissue kallikreins occur in the saliva of patients with connective tissue diseases, $\stackrel{?}{=}$ including RA (Greaves, Whicher, Bhoola et al, $\AA_{\infty}$ unpublished data). This finding led to a proposal ${ }^{+}$ that such a change may occur in joint fluids. As a first step it was necessary to identify tissue kallikrein $\overrightarrow{\mathbb{D}}$ in synovial fluid and distinguish it from known $\frac{?}{\mathbb{Q}}$ amidases like plasma kallikrein and elastase. ${ }^{14}$ 
In the present study we measured amidase, immunoreactive tissue kallikrein, and kininogenase concentrations in synovial fluid from the knee joints of patients with RA. As normal synovial fluid was unavailable patients with $\mathrm{OA}$ were used as a comparative group. In addition, we investigated the tissue site and possible source of immunoreactive tissue kallikrein in the synovial fluid.

\section{Patients and methods}

\section{PATIENTS}

Twenty four patients (nine men and 15 women, mean age 60.7 years, range $38-75$ years) were diagnosed as definite or classical RA according to American Rheumatism Association criteria. ${ }^{15}$ One patient in this group had both knees aspirated, and two patients each had the same knee aspirated on two separate visits, making a total of 27 samples. Twelve patients (two men and 10 women, mean age $70 \cdot 8$ years, range $55-90$ years) had OA diagnosed by standard clinical and $x$ ray assessments and from the analysis of synovial fluid. Two patients in this group had both knees aspirated, making a total of 14 samples. One rheumatoid synovial fluid was used for kininogenase measurement. For immunocytochemistry synovial fluid pellets and biopsy specimens of inflamed synovial membrane were obtained from 15 patients with RA undergoing therapeutic arthroscopy.

\section{SAMPLE COLLECTION}

Synovial fluid samples were collected in plain tubes. Samples were spun at $12500 \mathrm{~g}$ for five minutes at $4^{\circ} \mathrm{C}$ in a microcentrifuge (Burkard, Coolspin). The pellets from 15 samples were fixed for immunocytochemistry. The supernatants were stored at $-70^{\circ} \mathrm{C}$. Immediately before assay each sample was treated with hyaluronidase $(22.5 \mathrm{IU} / \mathrm{ml}$ supernatant $)$ for 30 minutes at $37^{\circ} \mathrm{C}$.

\section{ENZYME ACTIVITY}

Amidase activity was measured using the selective tissue kallikrein synthetic substrate H-D-Val-LeuArg-pNA (S-2266, Kabi Diagnostica); enzymic cleavage of the substrate produces $p$-nitroaniline (pNA). ${ }^{16}$ The reaction was carried out at $37^{\circ} \mathrm{C}$ and pH 8.2 in the presence of soybean trypsin inhibitor (cuvette concentration $125 \mu \mathrm{g} / \mathrm{ml}$ ). The rate of increase in absorption at $405 \mathrm{~nm}$ was followed on a Unicam SP1800 spectrophotometer. The activity of amidase resistant to soybean trypsin inhibitor was expressed as tissue kallikrein equivalents in $\mathrm{mU} / \mathrm{ml}$, where one unit $(U)$ of tissue kallikrein hydrolyses $1 \mu \mathrm{mol} /$ litre substrate per minute. To measure the proenzyme amidase activity the sample was acti- vated with bovine trypsin $(100 \mu \mathrm{g} / \mathrm{ml})$ for 15 minutes at $37^{\circ} \mathrm{C}$. The reaction was stopped with soybean trypsin inhibitor $(100 \mu \mathrm{g} / \mathrm{ml})$ and the tissue kallikrein equivalent activity measured as before. ${ }^{17}$ Activity of the proenzyme (inactive) was determined by subtracting the value for active from that obtained after trypsinisation. The concentration of soybean trypsin inhibitor $(125 \mu \mathrm{g} / \mathrm{ml})$ in the reaction mixture was sufficient to inhibit the activity of plasma kallikrein $(14.5 \mu \mathrm{g} / \mathrm{ml})$ and elastase $(3.75 \mu \mathrm{g} / \mathrm{ml})$ on the H-D-Val-Leu-Arg-pNA substrate. The amidases resistant to soybean trypsin inhibitor (active and proenzyme) were almost completely (90\%-95\%) inhibited by aprotinin $(5000 \mathrm{kIU} / \mathrm{ml})$.

$\beta$-Glucuronidase activity was measured by the method of Fishman with minor modifications. ${ }^{18}$ Lactate dehydrogenase activity was measured colorimetrically with a Sigma diagnostic kit.

\section{RADIOIMMUNOASSAY FOR TISSUE}

\section{K A L L I KRE I N}

Tissue kallikrein was measured by radioimmunoassay by the method of Bagshaw et al. ${ }^{19}$ The rabbit antihuman urinary kallikrein antiserum, raised in our laboratory, is known to have a high specificity for human tissue kallikreins. ${ }^{19}$ Elastase showed no cross reactivity with antihuman urinary kallikrein either in the radioimmunoassay or in immunoblots performed on cellulose nitrate paper.

PROTEIN

The protein content of the samples was measured by the Coomassie blue dye binding method of Bradford. ${ }^{20}$

\section{KININOGENASE ASSAY}

To measure the kininogenase activity of tissue kallikrein in the synovial fluid it was first necessary to deplete endogenous kininogen and inhibit plasma kallikrein present in the synovial fluid. Freeze dried synovial fluid, equivalent to $150 \mu \mathrm{l}$ of the original sample, was reconstituted in $50 \mathrm{mM} \mathrm{NaH} \mathrm{PO}_{4} \mathrm{pH}$ 7.4 and mixed with $100 \mu \mathrm{l}$ of a freshly prepared solution of bovine trypsin $(22 \mu \mathrm{g})$ in the same buffer. Firstly, the mixture was incubated for 15 minutes at $37^{\circ} \mathrm{C}$ to consume all endogenous kininogen. Next, soybean trypsin inhibitor (150 $\mu \mathrm{g}$ in the same buffer) was added to inhibit the bovine trypsin as well as the plasma kallikrein; the incubation was continued for 10 minutes at $37^{\circ} \mathrm{C}$ and a further 10 minutes at room temperature to permit degradation of kinin by kininases known to be present in synovial fluid. This reaction mixture was subsequently assayed for free kinin and for kininogenase activity and its inhibition by aprotinin, according to the methods described by Fink et $a{ }^{21}$ 
To measure free kinin the final incubate was mixed with absolute ethanol $(1 \mathrm{ml})$ and heated for 10 minutes to $70^{\circ} \mathrm{C}$. After centrifugation the supernatant was removed quantitatively, evaporated, and the dried residue analysed for kinin. ${ }^{21}$

To measure the kininogenase activity and its inhibition by aprotinin two aliquots $(50 \mu \mathrm{l})$ of the final incubate were mixed, one with $100 \mathrm{mM}$ $\mathrm{NaH}_{2} \mathrm{PO}_{4}, 3 \mathrm{mM}$ 1,10-phenanthroline, $30 \mathrm{mM}$ edetic acid $\mathrm{pH} 8.5$ and the other, in addition, with aprotinin solution $(5 \mu \mathrm{g} / \mathrm{ml}$ in the same buffer). After 10 minutes at room temperature (to allow complex formation with aprotinin) kininogenase activity was determined as described by Fink et al. ${ }^{21}$ In brief: the sample $(50 \mu \mathrm{l})$ was incubated with dog kininogen at $37^{\circ} \mathrm{C}$ for 30 minutes in the presence of kininase inhibitors; next, ethanol was added to stop the reaction and precipitate proteins. After centrifugation the supernatant (which contained the released kinin) was evaporated to dryness. The dried residue was dissolved and the solution analysed for the presence of kinin by radioimmunoassay. ${ }^{21}$ After subtracting the value for free kinin (see above) prokininogenase activity was calculated as fmoles kinin released per minute by $1 \mathrm{ml}$ of synovial fluid.

\section{M M U N OCY T OC H E M IS T R Y}

Pellets from synovial fluid samples and synovial membrane biopsy specimens were fixed in $4 \%$ formal-saline for 12-18 hours and embedded in paraffin wax. Serial sections from paraffin wax embedded samples were immunostained according to the peroxidase-antiperoxidase method. ${ }^{22}$ Before incubation with antibodies to human tissue kallikrein (purified from either saliva or urine ${ }^{19}$ ) the sections were treated with methanol and hydrogen peroxide to block endogenous pseudoperoxidase activity. ${ }^{23}$ Controls included preabsorption of the primary antiserum with purified human urinary kallikrein $(40 \mu \mathrm{g} / \mathrm{ml})$ and omission of the primary antiserum to confirm absence of residual pseudoperoxidase activity after treatment with methanol and hydrogen peroxide. After staining sections were counterstained with Giemsa or haematoxylin.

S T A T IS T I C S

All results except kininogenase activity are ex- $\frac{0}{\square}$ pressed per $\mathrm{mg}$ protein in the synovial fluid. The $\mathbb{Q}$ data were analysed using the two sided Mann- क Whitney $U$ test and the Spearman rank correlation coefficient. $^{24}$

MAT E R I A LS

All reagents used were of analytical reagent grade or purer and, except where stated, were obtained from Sigma Chemicals, Poole, Dorset.

\section{Results}

AMIDASE ACTIVITY AND

RADIOIMMUNOAS SA Y

Measurements were analysed in relation to patients

Table 1 Results of measurements on patients with rheumatoid arthritis $(R A)$ and osteoarthritis $(O A)$. Results $\odot \vec{\varphi}$ are presented as mean (SEM)

\begin{tabular}{|c|c|c|c|}
\hline & $R A$ & $O A$ & p Values \\
\hline $\begin{array}{l}\text { Active amidase } \\
(\mathrm{mU} / \mathrm{mg} \text { protein) }\end{array}$ & $0.023(0.003)$ & $0.006(0.002)$ & 0.001 \\
\hline $\begin{array}{l}\text { Inactive amidase } \\
(\mathrm{mU} / \mathrm{mg} \text { protein })\end{array}$ & $11 \cdot 2(0 \cdot 5)$ & $13 \cdot 4(1 \cdot 1)$ & $0 \cdot 1$ \\
\hline $\begin{array}{l}\text { Immunoreactive } \\
\text { tissue kallikrein } \\
\text { (ng/mg protein) }\end{array}$ & $0.155(0.011)$ & $0.205(0.012)$ & 0.01 \\
\hline $\begin{array}{l}\beta \text {-Glucuronidase } \\
\text { (OD units/mg } \\
\text { protein) }\end{array}$ & $0.011(0.001)$ & $0.007(0.001)$ & 0.001 \\
\hline $\begin{array}{l}\text { Lactic dehydro- } \\
\text { genase (units/mg } \\
\text { protein) }\end{array}$ & $104 \cdot 6(9 \cdot 3)$ & $38 \cdot 5(5 \cdot 1)$ & 0.001 \\
\hline Protein $(\mathrm{mg} / \mathrm{ml})$ & $40.5(1.5)$ & $33.3(0.9)$ & 0.002 \\
\hline
\end{tabular}

*OD=optical density.

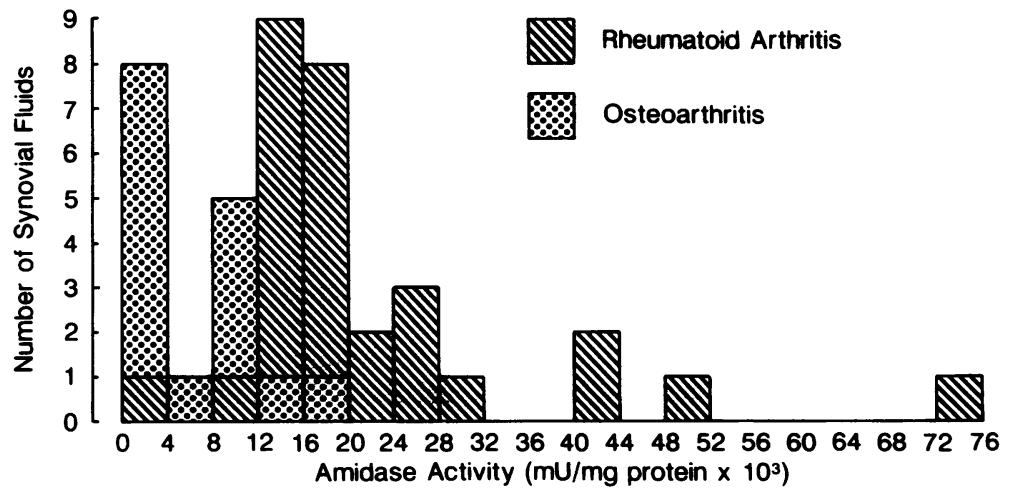

Fig. 1 Distribution of soybean trypsin inhibitor resistant amidase levels reflecting active tissue kallikrein, measured in synovial fluids from patients with rheumatoid arthritis and osteoarthritis. 

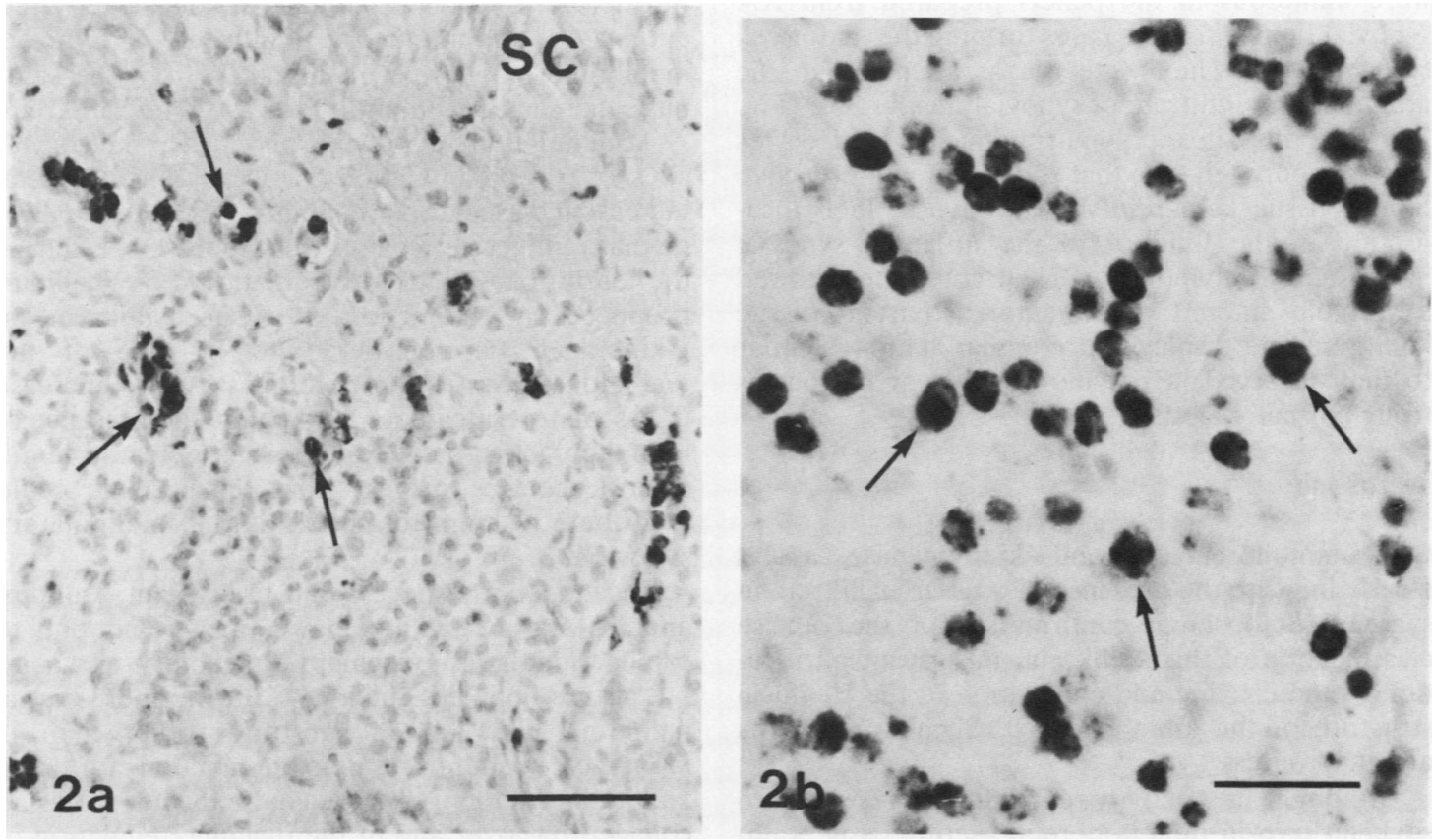

Fig. 2 Immunoreactive tissue kallikrein is visualised in polymorphonuclear leucocytes (arrows) present (a) in the inflammatory infiltrate of the synovial membrane and $(b)$ in the synovial fluid pellet. Only polymorphonuclear leucocytes show immunostaining, whereas the synovial cells (SC), lymphocytes, and macrophages remain unstained. (a) $b a r=15 \mu \mathrm{m}$; (b) $b a r=25 \mu \mathrm{m}$.

age, sex, and disease classification. None of the factors measured varied with patients' age, and no significant sex differences were found. Table 1 gives the results from the RA and OA groups. Levels of active amidase resistant to soybean trypsin inhibitor (tissue kallikrein equivalent) (Fig. 1) were significantly higher in RA than in OA $(p<0.001)$. Conversely, neither inactive amidase nor immunoreactive tissue kallikrein showed any significant difference between the RA and OA groups; nor did they correlate with one another or with any other factor. In all patients most of the tissue kallikrein equivalent enzymic activity seemed to be present in the precursor form. In addition to the subjects with RA we examined two female patients with psoriatic arthritis and two male patients with monarthritis; all four had levels of active amidase resistant to soybean trypsin inhibitor above $0.015 \mathrm{mU} / \mathrm{mg}$ protein. Conversely, in seven out of 14 patients with $\mathrm{OA}$ and in one patient with RA in a quiescent phase no such amidase activity was measurable in the joint fluid.

The mean values for $\beta$-glucuronidase and lactic dehydrogenase activities were significantly higher in
RA than in OA $(\mathrm{p}<0.001$ in both cases). Total protein concentration was also higher in RA $(p<0.002)$. A correlation of 0.67 was obtained between $\beta$-glucuronidase and lactic dehydrogenase activities. These parameters also correlated well with active amidase resistant to soybean trypsin inhibitor $(0.66$ for $\beta$-glucuronidase, 0.62 for lactic dehydrogenase).

\section{KININOGENASE ACTIVITY}

The kinin released by trypsin activation of tissue prokallikrein in synovial fluid was $491 \mathrm{fmol} / \mathrm{min} / \mathrm{ml}$. This kininogenase activity was completely inhibited by aprotinin but not by soybean trypsin inhibitor; an inhibitor profile which strongly suggests that kininogenase is a tissue kallikrein. Purified human urinary kallikrein under these assay conditions released $73 \mathrm{fmol} / \mathrm{min} / \mathrm{ng}$ of kinin. ${ }^{21}$ The kininogenase activity in synovial fluid corresponded to a concentration of $6.7 \mathrm{ng} / \mathrm{ml}$ of tissue kallikrein as measured by radioimmunoassay.

I M MUNOCYTOCHEMISTRY

Immunoreactive polymorphonuclear leucocytes 
were numerous in the pellets prepared from RA synovial fluids; in some cases forming the major cell type (Fig. 2). They were not as abundant in the inflammatory infiltrate of synovial membranes (Fig. 2). At both sites polymorphonuclear leucocytes were the only cell type that showed immunoreactive human tissue kallikrein. Irrespective of their localisation in the fluid or in the inflamed synovial membranes, polymorphonuclear leucocytes showed a variable amount of immunoreactivity to tissue kallikrein and displayed a granular staining similar to that observed in polymorphonuclear leucocytes from normal blood. ${ }^{25}$

\section{Discussion}

Our immunoreactive and kininogenase assays clearly indicate the presence of a tissue kallikrein in synovial fluid. Final confirmation of the precise classification of this kallikrein must await purification of the enzyme and elucidation of the chemical structure of the kinin released. Such experiments are in progress.

Although the activity of amidase resistant to soybean trypsin inhibitor, representing tissue kallikrein, was present in every RA synovial fluid examined, most seemed to be in an inactive form. Urinary tissue prokallikrein is converted to active tissue kallikrein by the loss of seven amino acids. ${ }^{26}$ A similar proenzyme may be present in synovial fluid either alone or bound in a complex with a selective inhibitor. Active tissue kallikrein is able to form inactive complexes with selective protease inhibitors. ${ }^{27}$ Hence trypsinisation may be activating free or bound tissue prokallikrein or exposing the active site of bound active tissue kallikrein. In either case dissociation of the complex need not necessarily occur for detection of the enzyme. The major tissue kallikrein inhibitor in human plasma ${ }^{28}{ }^{29}$ also abundant in synovial fluid, ${ }^{30}{ }^{31}$ is probably functionally important in regulating this enzyme in the joint. The enzyme value attributed to inactive amidase (see Table 1) may be due both to the activity of trypsin bound to $\alpha_{2}$ macroglobulin and to tissue kallikrein, converted from its proenzyme form by trypsinisation. Amidase activity of the trypsin- $\alpha_{2}$ macroglobulin complex, like tissue kallikrein, is resistant to soybean trypsin inhibitor.

An amidase resistant to soybean trypsin inhibitor with kinin forming activity has previously been described in synovial biopsy specimens taken from rat, dog, and man by Al-Haboubi and colleagues. ${ }^{32}$ Our results demonstrate for the first time, however, that polymorphonuclear leucocytes, present in large numbers in the synovial fluid from patients with RA, contain immunoreactive tissue kallikrein.
Furthermore, polymorphonuclear leucocytes present in the inflammatory infiltrates of synovia $\bar{p}$. membrane biopsy specimens taken from the same patients reacted with antibodies to tissue kallikrein?

Accumulation of polymorphonuclear leucocytes at sites of inflammation is accompanied by an increase in vascular permeability. ${ }^{33}$ Several types of mediator affect permeability of blood vessels during the early phases of inflammation. ${ }^{34} 35$ Kallidin, produced by the action of tissue kallikrein on $\vec{b}$ L-kininogen, is considered to be one of the mediators. It causes constriction of venules, increase्ल in vascular permeability, and pain. The presence of immunoreactive tissue kallikrein in polymorphonu $\overrightarrow{0}$ clear leucocytes suggests that this enzyme couldo contribute to kinin formation during inflammatoryin synovitis.

Recent reports suggest that bradykinin, kallidin ${ }^{\infty}$ and des-Arg' ${ }^{9}$-bradykinin may contribute not only to capillary dilatation, vascular permeability, and pain $\overrightarrow{\vec{T}}$ but also to bone destruction. ${ }^{4}$ Furthermore, tissued kallikrein may act on substrates other than $L$ 늘 kininogen. ${ }^{12}$ Therefore, possible functions for tissue kallikrein in joint disease could include roles in collagen turnover and in the dynamic regulation $\overline{6} 6$ bone forming cells. Tissue kallikrein and kalliक्षin ${ }^{6}$ can be added to the list of potential mediators synovitis and joint damage.

The excellent technical assistance of Mrs G Godec is gratefully acknowledged. We thank the special trustees of the Bristol ande Weston Health Authority and the Arthritis and Rheumatism $\overrightarrow{\vec{\sigma}}$ Council for financial support.

\section{References}

1 Schachter M. Kallikreins (kininogenases)-a group of serined proteases with bioregulatory actions. Pharmacol Rev 1980; 31:ฮె $1-17$.

2 Lewis G P. Kinins in inflammation and tissue injury. In: Erdos E G, ed. Handbook of experimental pharmacology. Vol XXV. Bradykinin, kallidin and kallikrein. Berlin-Heidelberg: Springer, 1970: $516-30$.

3 Melmon K L, Webster M E, Goldfinger S E, Seegmiller J E.을 The presence of a kinin in inflammatory synovial effusion from arthritides of varying etiologies. Arthritis Rheum 1967; 10:0 13-20.

4 Lirner U H, Jones I L, Gustafson G T. Bradykinin, a new N potential mediator of inflammation-induced bone resorption. Arthritis Rheum 1987; 30: 530-40.

5 Gustafson G T, Ljunggren $O$, Boonekamp $P$, Lerner U.N Stimulation of bone resorption in cultured mouse calvaria by $\omega$ lys-bradykinin (kallidin), a potential mediator of bone resorption linking anaphylaxis processes to rarefying osteitis. Boneo and Mineral 1986; 1: 267-77.

6 Armstrong D, Jepson J B, Keele C A, Stewart J W. Pain- $\stackrel{\mathbb{D}}{-}$ producing substance in human inflammatory exudates and plasma. J Physiol (Lond) 1957; 135: 350-70.

7 Eisen V. Urates and kinin formation in synovial fluid. Proceed $-\bar{O}$ ings of the Royal Society of Medicine 1966; 59: 302-7.

8 Eisen V. Plasma kinins in synovial exudates. Br J Exp Pathol 1970; 51 : $322-7$. 
9 Kellermeyer R W, Breckenridge R T. The inflammatory process in acute gouty arthritis. 1. Activation of Hageman factor by sodium urate crystals $J$ Lab Clin Med 1965; 65: $307-15$

10 Jasani M K, Katori M, Lewis G P. Intracellular enzymes and kinin enzymes in synovial fluid in joint diseases. Ann Rheum Dis 1969; 28: 497-512.

11 Suzuki M, Ito A, Mori Y, Hayashi Y, Matsuta K. Kallikrein in synovial fluid with rheumatoid arthritis. Biochemical Medicine and Metabolic Biology 1987; 37: 177-83.

12 Fuller $\mathrm{P}$ J, Funder $\mathrm{J}$ W. The cellular physiology of glandular kallikrein. Kidney Int 1986; 29: 953-64.

13 Fink E, Geiger R, Witte J, Biedermann S, Seifert J, Fritz H. Biochemical, pharmacological, and functional aspects of glandular kallikreins. In: Gross F, Vogel H G, eds. Enzymatic release of vasoactive peptides. New York: Raven Press, 1980: 101-15.

14 Movat H Z. The plasma kallikrein-kinin system and its interrelationship with the other components of blood. In: Erdos E G, ed. Handbook of experimental pharmacology. Vol XXV suppl. Bradykinin, kallidin and kallikrein. Berlin-Heidelberg: Springer, 1979: 1-87.

15 Ropes M W, Bennett G A, Cobb S, Jacox R, Jessar R A. 1958 revision of diagnostic criteria for rheumatoid arthritis. Arthritis Rheum 1959; 2: 16-20.

16 Amundsen E, Putter J, Friberger P, Knos M, Larsbraten M, Glaeson G. Methods for the determination of glandular kallikrein by means of a chromogenic tripeptide substrate. In: Fujii S, Moriya H, Suzuki T, eds. Advances in experimental medicine and biology. Vol 120A. Kinins II. New York: Plenum Press, 1979: 83-95.

17 Lauar N, Bhoola K D. Release of tissue kallikrein from the isolated perfused kidney. In: Greenbaum L M, Margolius H S, eds. Advances in experimental medicine and biology. Vol 198A. Kinins IV. New York: Plenum Press, 1986: 347-54.

18 Fishman W H. B-Glucuronidase. In: Bergmeyer $\mathrm{H} \mathrm{U}$, ed. Methods of enzymatic analysis. Weinheim: Verlag Chemie, 1963: 869-74.

19 Bagshaw A F, Bhoola K D, Lemon M J C, Whicher J T Development and characterization of a radioimmunoassay to measure human tissue kallikrein in biological fluids. J Endocrinol 1984; 101: 173-9.

20 Bradford $M$ M. A rapid and sensitive method for the quantitation of microgram quantities of protein utilizing the principle of protein-dye binding. Anal Biochem 1976; 72: 248-54.

21 Fink E, Schill W B, Fiedler F, Krassnigg F, Geiger R, Shimamoto $\mathrm{K}$. Tissue kallikrein of human seminal plasma is secreted by the prostate gland. Biol Chem Hoppe Seyler 1985; 366: $917-24$.

22 Sternberger L A. Immunocytochemistry. New York: Wiley, 1979: 104-69.

23 Streefkerk J G. Inhibition of erythrocyte pseudoperoxidase activity by treatment with hydrogen peroxide following methanol. J Histochem Cytochem 1972; 20: 829-31.

24 Barlow R B. Biodata handling with microcomputers. Amsterdam: Elsevier, 1983.

25 Figueroa C D, MacIver A G, Dieppe P, Mackenzie J C, Bhoola $\mathrm{K} \mathrm{D}$. Presence of immunoreactive tissue kallikrein in human polymorphonuclear (PMN) leucocytes. In: Advances in experimental medicine and biology. Kinins $V$. New York: Plenum Press (in press).

26 Takahashi S, Irie A, Katayama Y, Ito K, Miyake Y. Activation mechanism of human urinary prokallikrein using trypsin as a model activator. Biochem Int 1987; 14: 467-74.

27 Hojima $\mathbf{Y}$, Isobe $\mathbf{M}$, Moriya $\mathbf{H}$. Kallikrein inhibitors in rat plasma. J Biochem 1977; 81: 37-46.

28 Sakamoto W, Nishikaze O, Uno S, Yoshikawa K, Uehara S. Relationship between salivary kallikrein, kininogen and plasma proteinase inhibitors. In: Fritz $H$, Dietze $G$, Fiedler $F$, Haberland G L, eds. Agents and actions. Suppl 9. Recent progress on kinins. Basel: Birkhauser, 1982: 184-9.

29 Geiger R, Hofmann W, Franke M, Baur X. Biochemistry of human tissue kallikrein. In: Fritz H, Back N, Dietze G, Haberland G L, eds. Advances in experimental medicine and biology. Vol 156A. Kinins III. New York: Plenum Press, 1983: 275-88.

30 Brackertz D, Hagmann J, Kueppers F. Proteinase inhibitors in rheumatoid arthritis. Ann Rheum Dis 1975; 34: 225-30.

31 Robinson A D, Boyden K N. Hendrickson S M, Muirden K D. Antitrypsin activity and enzyme inhibitors in the rheumatoid joint. J Rheumatol 1981; 8: 547-54.

32 Al-Haboubi H A, Bennett D, Sharma J N, Thomas G R, Zeitlin I J. A synovial amidase acting on tissue kallikreinselective substrate in clinical and experimental arthritis. In: Greenbaum L M, Margolius H S, eds. Advances in experimental medicine and biology. Vol 198B. Kinins IV. New York: Plenum Press, 1986: 405-11.

33 Majno G, Palade G E. The effect of histamine and serotonin on vascular permeability: an electron microscopic study. Journal of Biophysics and Biochemical Cytology 1961; 11: 571-605.

34 Spector W G. Willoughby D A. Vasoactive amines in acute inflammation. Ann NY Acad Sci 1964; 116: 839-46.

35 Greenbaum L M. Kininogenases of blood cells (alternate kinin generating systems). In: Erdos E G, ed. Handbook of experimental pharmacology. Vol XXV suppl. Bradykinin, kallidin and kallikrein. Berlin-Heidelberg: Springer, 1979: 91-102. 